\title{
The Effect of Self-Financing on Learning Motivation with Mediation of Training Quality
}

\section{Endang Setyowati*}

Postgraduate Scholar Program of Management Magistrate, Economic Faculty, Gajayana University-Malang, Indonesia unigamalang2@gmail.com

\section{Dyah Sawitri}

Postgraduate Scholar Program of Management Magistrate, Economic Faculty, Gajayana University-Malang, Indonesia

${ }^{*}$ Corresponding author

\begin{abstract}
This study aims to examine the effect of Self-financing on Training quality and the impact on learning motivation of trainees at UPT BLK singosari-Malang. This research is important because in the researchers knowledge it has never been studied before and can contribute to Singosari BLK UPT to determine appropriate Selffinancing and training. The study population was 60 participants who had attended training at UPT BLK Singosari during 2019 using Selffinancing. Because the samples are small, this study uses a census sample, where a total of 60 people are sampled. Data collection uses a questionnaire. Data was obtained by distributing a list of questions about the Self-financing variable and Training quality in relation to learning motivation to respondents. The data obtained were analyzed by multiple regression analysis and path analysis. The results showed that Self-financing directly has a significant effect on Training quality variable. Self-financing directly has a significant effect on variable Learning motivation. The Training quality directly has a significant effect on Learning motivation variable. Self-financing indirectly has a significant effect on Learning motivation mediated by Training quality.
\end{abstract}

Keywords: BLK Singosari, Self-financing, Training quality, Learning Motivation

\section{INTRODUCTION}

Development of employment sector is an integral part of national development. Labor is an important and potential factor to drive the wheels of development, especially in economic field. Potential labor will affect the national productivity and national income. The greater national productivity and income means better economic growth. The total population of East Java aged 15 years and over was 30,57 million people in 2017, the 21 million have entered the workforce, with 20,20 already employed while the remaining 0,81 are still unemployed. The number of unemployed people in East Java decreased from 0,84 million in 2017. However, number of unemployed is still quite large and requires serious treatment from government. 
One of government service to provide training is the UPT BLK Singosari-Malang. It is an institution that conducts job training for unemployed / job seekers in Malang and surrounding areas. The work training program at UPT BLK Singosari-Malang can be in line with expectations if it is based on good job training management, from planning, implementation, and evaluation of training program. Job training needs program management from planners, instructors, and other implementers. This is very important in order to smooth the implementation of job training programs. Sastrohadiwiryo (2002) stated that implementation of education and training for workers can be done inside or outside the company or other institutions or bodies outside the company.

UPT BLK Singosari Malang plays an important role to provide training to community in order to improve community skills in reducing unemployment. Funding in education is one of main considerations in education. Training as part of education also requires funding. Some important and strategic training for interests of nation is borne by state. However, some training is also outside the scope of state funding so that it requires Selffinancing from trainees to attend the training.

Funding for education and training is one of important issues in development. Developing countries generally spend their funds for education that relatively lower than in developed countries. The low education funding in developing countries has become a public discourse requiring a way out. One way out is to conduct independent training funded by trainees themselves. Changes in funding from being borne by government to trainees will certainly have a different impact on Training quality or the quality of education obtained. Based on these explanations, this study aims to examine the effect of Self-financing on Training quality and its impact on Learning motivation obtained by Participants at UPT BLK Singosari-Malang. This research is important because in knowledge of researchers has never been studied before and can contribute to UPT BLK Singosari-Malang in determining appropriate training.

\section{THEORETICAL REVIEW}

\section{Seff-Financing}

Financing is everything related to costs. The concept of costs is the money spent on establishing something, fees, and expenses (KBBI, 2018). Broadly speaking, costs are sacrifices of economic resources measured in units of money, which have occurred or are likely to occur for a particular purpose. In a narrow sense, self-financing can be interpreted as a self sacrifice of economic resources to obtain assets (Ferdi, 2013).

Mulyono (2010) explained that cost is a decisive element in budgeting mechanism. Cost has a very decisive role in every effort to achieve goals. Determination of costs will affect the level of efficiency and effectiveness of activities in an organization that will achieve a certain goal. Activities carried out at low cost and the results have good quality can be said to be carried out effectively and efficiently. 


\section{Training Quality}

Quality is the degree or level of good or bad something. Training quality is the degree of good and bad of training process. The Training quality is considered to have a very important role for effectiveness of training. The implementation of training should follow the general principles of training to benefit the participants and can achieve their objectives optimally (Nurdin, 2015). Yoder \& Tilley (1962) mentioned nine principles that generally accepted in training activities, namely (1) individual differences; (2) relation to job analysis; (3) motivation (4) active participation, (5) selection of trainees, (6) Selection of trainers; (7) trainers of training (8) training methods and (9) principles of learning. Training activities must pay attention to individual differences in training participants. The characteristics of trainees will color and determine the successful implementation of training.

There is no perfect method in training, but alternative methods can be found in accordance with characteristics of trainees. In this case there are minimum requirements that need to be considered by trainer when choosing training methods, namely (1) according to circumstances and number of targets; (2) sufficient in quantity and quality of material; (3) right to destination on the time; (4) Mandates should be easily accepted, understood and applied; and (5) low cost (Depdikbud, 1983).

\section{Learning Motivation}

Motivation comes from Latin word "movere", it means impulse or move. Motivation is human activity in directing power and potential to work towards its goals (Hasibuan, 2013). A person works because he wants to fulfill his daily needs. The desire of each person is different so that human behavior tends to vary at work. According to Vroom in Purwanto (2006), learning motivation refers to a learning process to affect individual choices on various types of desired activities. Campbell (2012) suggested that learning motivation includes the direction or purpose of learning behavior, response strength, and persistence of behavior. In addition, the term includes a number of concepts of drive, need, incentive, reward, reinforcement, goal setting, expectation, and so on.

\section{Conceptual framework and hypothesis}

To facilitate the theory explanation and empirical research proposed above, figure 1 shows research framework.

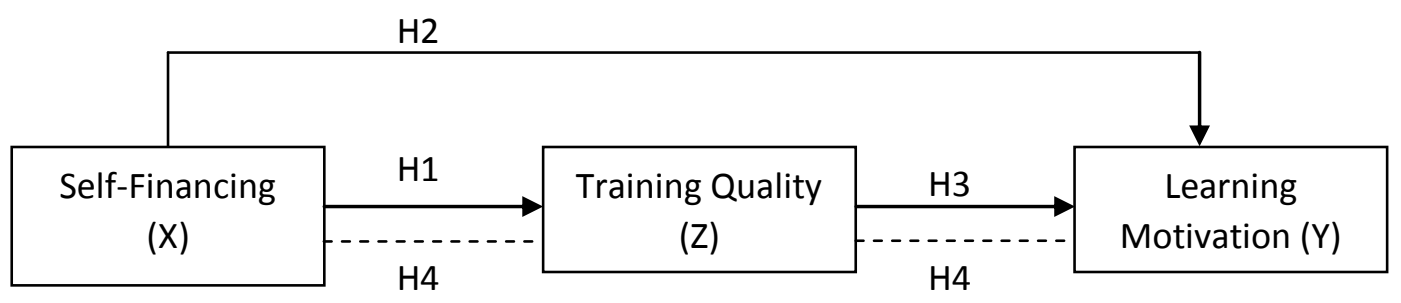

Figure 1. Research Conceptual Framework 
Based on conceptual framework of study, hypothesis of this study can be stated below.

H1: $\quad$ Self-financing directly affect on Training quality of trainees at UPT BLK Singosari Malang.

H2: Self-financing directly affect on Learning motivation at UPT BLK SingosariMalang.

H3: $\quad$ The Training quality directly affect on Learning motivation at UPT BLK SingosariMalang.

H4: Training quality mediates the effect of Self-financing on Learning motivation at UPT BLK Singosari-Malang.

\section{METHODOLOGY}

The research was located at UPT BLK Singosari-Malang, East Java. UPT BLK SingosariMalang was chosen as a research location because this location has often held training for prospective workers. The research type is explanatory research. According to Singarimbun \& Sofian (2009) explanatory research is a type of research that highlights the relationship between research variables and tests the formulated hypotheses. The study population was participants who had attended training at UPT BLK SingosariMalang during 2019 using Self-financing. The reason for selection of these criteria is because the training participants were more easily contacted. This is done to increase the response rate. The training participants sampled were 60 people. Data collection in this study used a questionnaire with five point Likert scale, starting from 1=strongly disagree, $2=$ agree, $3=$ neutral, 4=agree and $5=$ strongly agree (Ferdinand, 2014). Data was obtained by distributing a list of questions about the Self-financing variable and the Training quality in relation to Learning motivation to respondents. Path analysis is used to examine the relationship of direct or indirect variable (Solimun, 2010).

\section{RESEARCH RESULTS}

The construction of BLK in East Java began with establishment of Job Training Center (PLK) in Singosari and PLKP Wonojati in Malang in 1950s, along with six other PLKs in Indonesia. Singosari PLK is devoted to industry skills, while PLK Wonojati is in agriculture. Vocational industry means to train in building, radio and electricity. The training targets were job seekers, ex-combatants and employees from other agencies. PLK Singosari training facilities were obtained from assistance of Dutch Government.

The research data was collected using a questionnaire. Testing the validity of data shows that all instruments are reliable, based on a Pearson correlation value that is significant at 0,05 levels. The data also shows high validity, indicated by Cronbach's alpha greater than 0,6 (Ghozali, 2014).

The classical assumption test results show that data are normally distributed. The normal probability plot graph shows that data points spread around the diagonal line 
and the distribution follows the direction of diagonal line, thus the data distribution can be said to have a normal distribution so that regression model is feasible to predict Learning motivation $(\mathrm{Y})$ based on Self-financing variable $(\mathrm{X})$ and Training quality $(\mathrm{Z})$.

To detect the presence of multicollinearity can be seen from Value Inflation Factor (VIF). If the VIF value $>10$ then multicollinearity occurs. Conversely, if VIF <10, multicollinearity does not occur. Independent variables do not occur multicollinearity with indicated VIF value of each independent variable smaller than 10.

Heteroscedasticity is a condition in which there is a variance in residuals variance of one observation to another. A data does not have heteroscedasticity if the points on heteroscedasticity graph show patterns spreading above and below 0 . The results of data analysis show that points spread above and below zero and do not form certain patterns. Therefore it can be said that data obtained do not show heteroscedasticity so that further analysis can be done.

Hypothesis testing uses multiple regression analysis to examine the effect of independent variables on dependent variable directly. Meanwhile, testing for indirect effects is carried out using the sobel test method. The results of testing using multiple regression analysis for the effect of Self-financing $(X)$ and Training quality $(Z)$ variables on Learning motivation $(\mathrm{Y})$ are presented in Table 1 and Table 2.

Table 1. Results of Multiple Regression Analysis

\begin{tabular}{lrrrrrr}
\hline Variable & $\begin{array}{l}\text { Regression } \\
\text { coefficient } \\
\text { (b) }\end{array}$ & $\begin{array}{l}\text { Standard } \\
\text { deviation. } \\
\text { Error (B) }\end{array}$ & Beta $(\boldsymbol{\beta})$ & $\mathbf{t}_{\text {count }}$ & Sig. & Description \\
\hline Constant & 3,344 & 2,605 & & 1,283 &, 204 & \\
X &, 947 &, 161 &, 612 & 5,892 &, 000 & Significant \\
\hline Dependent Variable & & & $=$ Training quality (Z) & & \\
R Square & & & $=0,374$ & & \\
e1 & & & $=1-R^{2}=1-0,374=62,6$ & & \\
\hline
\end{tabular}

Table 2. Recapitulation of Multiple Regression Analysis

\begin{tabular}{|c|c|c|c|c|c|c|}
\hline Variable & $\begin{array}{l}\text { Regression } \\
\text { coefficient } \\
\text { (b) }\end{array}$ & $\begin{array}{l}\text { Standard } \\
\text { deviation. } \\
\text { Error (B) }\end{array}$ & Beta $(\beta)$ & $t_{\text {count }}$ & Sig. & Description \\
\hline Constant & 9,160 & 1,755 & & 5,219 & ,000 & \\
\hline $\mathrm{x}$ & ,654 & ,135 &, 551 & 4,844 &, 000 & Significant \\
\hline Z & ,194 & ,087 & ,254 & 2,230 &, 030 & Significant \\
\hline \multicolumn{3}{|c|}{ Dependent Variable } & \multicolumn{3}{|c|}{$=$ Learning motivation $(\mathrm{Y})$} & \\
\hline $\begin{array}{l}\text { R Square } \\
\text { e1 }\end{array}$ & & & \multicolumn{3}{|c|}{$=0,539$} & \\
\hline
\end{tabular}


Table 1 shows that Self-Financing variable $(X)$ has a beta coefficient of 0,612 with a significance value ( $p$-value) of $0,000<0,05$. This means that $\mathrm{H}_{1}$ is accepted, there is a significant effect of Self-Financing $(X)$ on Training quality $(Z)$. Thus from this study it can be concluded that Self-financing $(X)$ directly has a significant and positive effect on Training quality.

Hypotheses 2 and 3 testing are conducted to determine the direct effect of Selffinancing $(X)$ and Motivation $(Z)$ on Learning motivation $(Y)$. The first time an analysis of effect of Self-financing $(X)$ was carried out on Learning motivation ( $Z$ ). Table 2 shows that Self-financing variable $(X)$ has a beta coefficient of 0,551 with a significance value ( $p$ value) of $0,000<0,05$. This means that $\mathrm{H}_{2}$ is accepted, there is a significant effect of Selffinancing $(X)$ on Learning motivation $(Y)$.

Hypothesis 3 testing was conducted to determine the direct effect of Training quality ( $Z$ ) on Learning motivation $(\mathrm{Y})$. Table 2 shows that Training quality variable $(\mathrm{Z})$ has a beta coefficient of 0,251 with a significance value ( $p$-value) of $0,037<0,05$. This means that $\mathrm{H}_{3}$ is accepted, there is a significant effect of Training quality $(\mathrm{Z})$ on Learning motivation $(\mathrm{Y})$.

The indirect effect of independent variable on dependent variable can be determined by multiplying the value of direct effect (standardized beta coefficient) on each equation. This study examines the indirect effect of Self-financing variable $(X)$ on learning motivation ( $\mathrm{Y}$ ) through Training quality $(\mathrm{Z})$ as a mediating variable. To make it easier to understand the relationship between the variables studied, Figure 1 shows the results of data analysis.

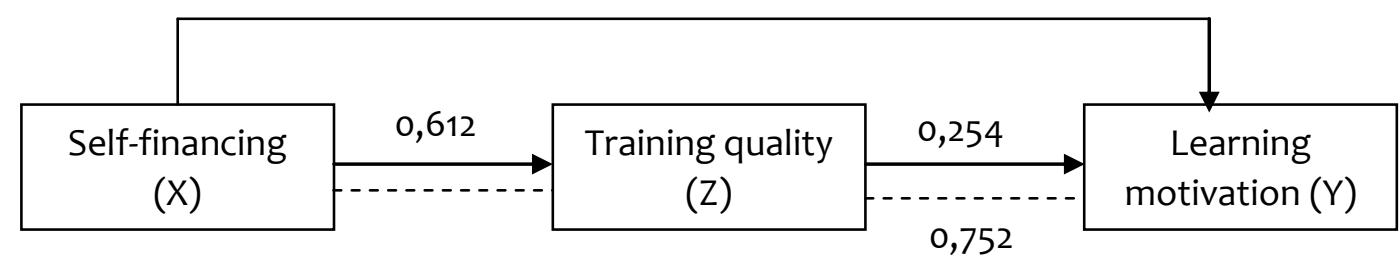

Description:

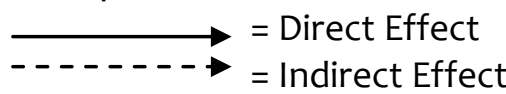

Figure 2. Research Results

The results from calculation above can be explained : there is a significant positive and direct effect of Self-financing variable on Training quality at 0,612 . There is a significant positive and direct effect between variable of Self-financing on $Y$ at 0,551 . There is a significant positive and direct effect of Training quality on variable on Learning Motivation at 0,254 . There is a positive of Self-financing on Learning motivation mediated by $Z$ at 0,752 . 


\section{DISCUSSION}

\section{Direct Effect of Self-financing on Training quality}

Above analysis results shows that Self-financing has a direct and significant effect on Training quality of trainees at UPT BLK Singosari-Malang. The implementation of Selffinancing from Singosari UPT BLK Singosari-Malang participants can improve the Training quality. The implementation of Self-financing can make the UPT BLK SingosariMalang trainees have better Training quality. The Self-financing at UPT BLK SingosariMalang makes training participants better to complete their assignments. The results of this study are in line with research conducted by Jiang et al. (2018), Nadiroh \& Wahjoedi (2016), Puspitasari et al. (2017) who found that Self-financing would be able to improve the Training quality. Improving the Training quality itself ultimately affect to increase the Learning motivation.

\section{Direct Effect of Self-financing on Learning motivation}

Self-financing has a direct and significant effect on Learning motivation of trainees at UPT BLK Singosari-Malang. Self-financing at UPT BLK Singosari-Malang for training participants will have an impact to improve the Learning motivation. The results of this study are in line with research conducted by Setiawan et al. (2015) who found that Selffinancing can improve Learning Quality if it is based on mutual trust. This statement is supported by Puspitasari et al. (2017) who state that imposition of education costs can improve the quality of learning.

\section{Direct Effect of Training quality on Learning motivation}

Training quality has a direct and significant effect on Learning motivation of trainees at UPT BLK Singosari-Malang. Improving the Training quality can increase the Learning motivation of UPT BLK Singosari-Malang trainees. High quality training will certainly make of trainees at UPT BLK Singosari-Malang can provide the best contribution in job market. This contribution will certainly make you feel increasingly needed and valued. This of course will make work even harder and performance will increase. The results of this study are in line with Bergery et al. (2018) who found that Training quality would be able to improve Learning motivation.

\section{Indirect Effects of Self-financing on Learning motivation Mediated by Training quality}

Testing the indirect effect of Self-financing on Learning motivation of trainees at UPT BLK Singosari-Malang through the Training quality as a mediation variable showed significant results. The results of this indirect effect show a greater value than the direct effect that also significant. This shows that through the Training quality variable, indirect effect of Self-financing on Learning motivation is higher. Self-financing directly affect the Learning motivation. Training quality also mediates the effect of motivation on Learning motivation. Because both have significant effect, this mediation is a partial mediation, in which both the direct effect and indirect effect of mediation are equally significant. The results of this study are in line with research by Bergery et al. (2018) who found that 
Self-financing would improve the Training quality which in turn resulted in better Learning motivation.

\section{CONCLUSIONS AND RECOMMENDATIONS}

This research is an attempt to prove empirically about the theory which states that SelfFinancing can improve the Training quality and having an impact on Learning motivation. From results of analysis conducted at of trainees at UPT BLK Singosari-Malang, the conclusions below were obtained: Self-financing directly has a significant and positive effect on Training quality variable. This means that proper Self-financing will improve the Training quality of trainees in UPT BLK Singosari-Malang. Self-financing directly has a significant and positive effect on Learning motivation variables. This means that proper Self-financing can increase the Learning motivation of training participants at UPT BLK Singosari-Malang. Training quality directly has a significant and positive effect on Learning motivation variable. Appropriate motivational techniques can increase Learning motivation of trainees at UPT BLK Singosari-Malang. Self-financing indirectly has a significant effect on Learning motivation mediated by Training quality. This means that Self-financing indirectly affects Learning motivation mediated by Training quality of trainees at UPT BLK Singosari-Malang.

Above conclusions indicate several opportunities to improve Learning motivation. From conclusions above, suggestions below can be made. The UPT BLK Singosari-Malang should improve the Training quality and Learning motivation by determining Selffinancing that is in accordance with needs. Therefore, Self-financing should be implemented based on needs to improve the Training quality and in turn to increase the Learning motivation. Future researchers should conduct further research regarding the generalization of theory by adding three things. First, increasing the number of samples by including the scope of East Java or nationally. Second, this study only uses the Selffinancing variable as an independent variable. Outside of Self-financing there are many other variables to effect motivation and Learning motivation, such as work experience, education and or compensation. Therefore, these variables can be added to future research. Third, analysis tools used are still regression based; future research can use more accurate analysis tools such as GSCA or PLS.

Some limitations are: (1) to improve the analysis result for the effect of Self-financing on Learning motivation in Indonesia in general and the UPT BLK Singosari-Malang training participants, a more diverse sample is still needed. So it does not only look at one unit of UPT BLK Singosari-Malang training participants, but it can examine all the entire UPT BLK in Indonesia. (2) Self-financing variable used in this study is a single independent variable. To uncover the truth of theory as a whole, it is still necessary to add several variables related to motivation and Learning motivation so as to obtain more comprehensive findings. (3) The analytical tool used in this study with Path Analysis is limited to only seeing the relationship between variables. Thus it does not reveal the relationship between the indicators of each variable, especially the causal relationship between the indicators of Self-financing, Training quality and indicators Learning motivation. 


\section{REFERENCES}

Badan Pengembangan dan Pembinaan Bahasa, Kamus Besar Bahasa Indonesia, https://kbbi.kemdikbud.go.id/entri/biaya, diakses pada 27 Juni 2018 pkl. 20:49

Nadiroh, F. \& Wahjoedi. (2016). Pengaruh Pemanfaatan Bantuan Dana Pendidikan dan Motivasi Belajar Terhadap Hasil Belajar Mahasiswa S1 Pendidikan Ekonomi Angkatan 2012 Universitas Negeri Malang. Jurnal Pendidikan Ekonomi, 9(1), 22-30.

Bergey, B. W., Parrila, R. K., \& Deacon, S. H. (2018). Understanding the academic motivations of students with a history of reading difficulty: an expectancy-valuecost approach. Learning and Individual Differences, 67, 41-52. https://doi.org/10.1016/j.lindif.2018.06.008

Campbell, J. P. (2002). Modeling the Performance Prediction Problem in Industrial and Organizational Psychology, Handbook of Industrial and Organizational Psychology, Volume 1. ed. Marvin D. Dunnette and Leaette M. Hough. Mumbai: Jaico Publishing House.

Depdikbud RI. (1993). Basic Education Curriculum GBPP SMP Indonesian Language Subjects. Jakarta: Depdikbud RI.

Ferdi, W. P. (2013) Pembiayaan Pendidikan dan pelatihan: Suatu Kajian Teoritis. Jurnal Pendidikan dan pelatihan dan Kebudayaan, 3(4), 568-575.

Ferdinand, A. (2014). Metode Penelitian Manajemen. Semarang: Badan Penerbit Universitas Diponegoro.

Ghozali, I. (2014). Aplikasi analisis Multivariate dengan Program SPSS. Semarang: Badan Penerbit UNDIP.

Hasibuan, M. (2013). Manajemen Sumber Daya Manusia. Jakarta: PT. Bumi Aksara.

Jiang, Emily Q, Rosenzweig and Gaspard. (2018). An expectancy-value-cost approach in predicting adolescent students' academic motivation and achievement. Contemporary Educational Psychology, 54, 139-152.

Mulyono. (2010). Konsep Pembiayaan Pendidikan dan pelatihan. Jogjakarta: Ar-Ruzz Media.

Nurdin, D. (2015). Pengelolaan Pendidikan dan pelatihan. Jakarta: PT RajaGrafindo Persada.

Puspitasari, N. I., Siswandari dan Nurhasan, H. (2017). Hubungan Antara Persepsi Siswa Tentang Program Pendidikan Gratis Dan Motivasi Belajar Dengan Prestasi Belajar. Jurnal Tata arta UNS, 3(2), 51-60.

Purwanto, N. (2006). Educational Psychology. Bandung: PT Remaja Rosdakarya.

Sastrohadiwiryo, S. (2002). Manajemen Tenaga Kerja Indonesia. Jakarta : Bumi Aksara. 
Setiawan, J., Riswan, D. dan Siti, F. (2015) Pengaruh Biaya Pendidikan dan Fasilitas Pendidikan terhadap Hasil Belajar Mata Pelajaran Ekonomi Peserta Didik SMA Bukit Asam Tanjung Enim. Jurnal Profit, 2(1), 14-27.

Singarimbun, M. dan Sofian, E. (2009). Metode Penelitian Survei. Jakarta: LP3ES.

Solimun. (2010). Analisis Multivariat Pemodelan Struktural Metode Partial Least SquarePLS. Malang : Citra.

Yoder, H.S \& Tilley, C. E. (1962). Origin of Basalt Magmas: An Experimental Study of Natural and Synthetic Rock Systems. Journal of Petrology, 3(3), 342-532. https://doi.org/10.1093/petrology/3.3.342 